\title{
Kualitas Mobile Banking Terhadap Kepuasan Nasabah Bank BRI (Studi Pada Pengguna BRI Mobile di Kota Depok)
}

\author{
Ratnawaty Marginingsih \\ Universitas Bina Sarana Informatika \\ e-mail: ratnawaty.rmg@bsi.ac.id

\begin{tabular}{ccc}
\hline Diterima & Direvisi & Disetujui \\
$15-01-2020$ & $16-01-2020$ & $21-01-2020$ \\
\hline
\end{tabular}

\begin{abstract}
Abstrak - Pemanfaatan teknologi pada industri perbankan seperti mobile banking atau sering disebut dengan $\mathrm{m}$ banking memberikan kemudahan dalam transaksi keuangan. Layanan yang terdapat pada mobile banking meliputi pembayaran, transfer, history, dan lain sebagainya. Penggunaan layanan mobile banking pada telepon seluler memungkinkan para nasabah dapat lebih mudah untuk menjalankan aktivitas perbankannya tanpa batas ruang dan waktu. Penelitian ini bertujuan untuk mengetahui pengaruh kualitas layanan mobile banking terhadap kepuasan nasabah Bank BRI di Kota Depok. Sebanyak 100 responden disurvei secara online menggunakan convenience sampling method. Bentuk penelitian yang digunakan adalah jenis penelitian deskriptif dengan pendekatan kuantitatif. Data diolah dengan dengan menggunakan analisis regeresi linier berganda. Hasil penelitian diperoleh faktor kualitas pelayanan secara parsial dan simultan dengan menggunakan variabel reliability and responsiveness, assurance and security, convenience in banking, mobile banking efficiency dan easy to use terhadap Kepuasan Nasabah memperoleh hasil yang positif dan signifikan. Hal ini menujukkan bahwa pelayanan yang baik menjadi salah satu kunci keberhasilan sebuah organisasi.
\end{abstract}

Kata Kunci : Kualitas Jasa, Kepuasan Nasabah, Mobile Bankng

\begin{abstract}
The utilization of technology in the banking industry such as mobile banking or often referred to as $m$-banking provides convenience in financial transactions. There are services on mobile banking, covering payments transfer, history, and others. The use of mobile banking services in cell phones allow that customers can more easily to run their banking activities indefinitely space and time.This study aims to determine the effect of the quality of mobile banking services on BRI Bank customer satisfaction in the city of Depok. A total of 100 respondents were surveyed online using the convenience sampling method. The form of research used is descriptive research with a quantitative approach. The data is processed using multiple linear regression analysis. The results of this study are obtained partially and simultaneously the quality of service using the variables reliability and responsiveness, assurance and security, convenience in banking, mobile banking efficiency and easy to use on customer satisfaction to obtain positive and significant results. This shows that good service is one of the keys to the success of an organization
\end{abstract}

Keywords : Service Quality, Customer Satisfaction, Mobile Banking

\section{PENDAHULUAN}

Perkembangan teknologi dan informasi yang sangat pesat di era globalisasi saat ini tidak dapat dipungkiri menjadi salah satu faktor pendukung keberhasilan sebuah organisasi dalam persaingan bisnis. Semakin mudah dan cepatnya mendapatkan informasi dengan menggunakan teknologi berdampak pada peningkatan interaksi antar individu untuk mendapat informasi yang dibutuhkan. Berdasarkan data dari Statista 2019 menunjukkan pengguna internet di Indonesia pada 2018 sebanyak 95,2 juta, tumbuh 13,3\% dari 2017 yang sebanyak 84 juta pengguna. Pada tahun selanjutnya pengguna internet di Indonesia akan semakin meningkat dengan rata-rata pertumbuhan sebesar $10,2 \%$ pada periode 2018-2023. Pada 2019 jumlah pengguna internet di Indonesia diproyeksikan tumbuh 12,6\% dibandingkan 2018, yaitu menjadi 107,2 juta pengguna. Pada 2023, jumlah pengguna internet di Indonesia diproyeksikan mencapai 150 juta pengguna (Jayani, 2019).

Teknologi informasi begitu penting dalam dunia bisinis tidak terkecuali sektor perbankan. Pemanfaataan penggunaan teknologi untuk memberikan pelayanan yang lebih baik kepada para nasabahnya bank meluncurkan media layanan transaksi perbankan berbasis teknologi informasi yaitu mobile banking (m-banking). Layanan mbanking membuka kesempatan bagi nasabah untuk 
melakukan transaksi perbankan melalui perangkat ponsel atau Personal Data Asistent (PDA) (Wardhana, 2015)

Mobile banking merupakan sebuah fasilitas dari bank dalam era modern ini yang mengikuti perkembangan teknologi dan komunikasi. Layanan yang terdapat pada mobile banking meliputi pembayaran, transfer, history, dan lain sebagainya. Penggunaan layanan mobile banking pada telepon seluler memungkinkan para nasabah dapat lebih mudah untuk menjalankan aktivitas perbankannya tanpa batas ruang dan waktu. Dengan adanya layanan mobile banking diharapkan dapat memberikan kemudahan dan manfaat bagi para nasabah dalam melakukan akses ke bank tanpa harus datang langsung ke bank (Kurniawati, et.al, 2017)

Saat ini hampir seluruh bank sudah mengaplikasikan m-banking sebagai salah satu peningkatan kulaitas pelayanan yang mampu menjawab kebutuhan masyarakat modern yang mengedepankan mobilitas. Layanan kualitas jasa elektronik atau E-SERVQUAL didefinisikan secara luas untuk mencakup semua tahap interaksi kepada pelanggan secara online. Dalam pelaksanaannya, proses E-SERVQUAL perlu memperhatikan efektifitas dan efisiensi dalam hal transaksi, pembelian atau pengiriman yang dilakukan. (Parasuraman, A.,et.al, 2005)

Kualitas layanan merupakan kunci dari ukuran kepuasan nasabah. Jika kinerja gagal memenuhi ekspektasi pelanggan, maka pelanggan tidak akan puas. Jika kinerja sesuai dengan ekspektasi pelanggan, maka pelanggan akan puas. Jika kinerja melebihi ekspektasi pelanggan, maka pelanggan akan sangat puas dan senang (Kotler, Philip., \& Keller, 2012)

Bank Rakyat Indonesia (Persero) Tbk, sebagai salah satu bank BUMN sangat memperhatikan peningkatan kualitas pelayanan perbankan sesuai dengan perkembangan zaman. Hal ini dapat terlihat dengan menghadirkan layanan perbankan berbasis tekonologi yakni BRI Mobile atau BRImo. BRImo merupakan pengembangan terbaru dari aplikasi BRI Mobile yang telah ada sebelumnya. Terdapat lebih dari 11 juta pengguna BRI Mobile dengan jumlah transaksi mencapai 575 juta sepanjang tahun lalu.

BRImo merupakan aplikasi digital banking milik PT Bank Rakyat Indonesia (Persero) Tbk, meraih 2,2 juta pengguna hanya dalam 8 bulan sejak diluncurkan pada Februari 2019 yang lalu. BRImo menjadi andalan BRI untuk menggaet nasabah baru terutama dari kalangan milennial. Beberapa keunggulannya adalah kemudahan dalam pembukaan rekening BRI Britama Muda, login dengan finger print/face recognition, dan akses info promo. Aplikasi ini menggabungkan fungsi mobile banking, internet banking, dan uang elektronik (Tbank) dalam satu aplikasi dengan menu transaksi yang lebih lengkap dan menarik.
Penelitian ini pada prinsipnya adalah untuk dapat melihat seberapa besar pengaruh kualitas pelayanan mobile banking terhadap kepuasan nasabah Bank BRI yang berada di kota Depok, Jawa Barat.

\section{METODOLOGI PENELITIAN}

Dalam penelitian ini, jenis penelitian yang digunakan adalah jenis penelitian deskriptif dengan pendekatan kuantitatif. Lokasi penelitian dilakukan di Depok Jawa Barat, sebanyak 100 responden disurvei secara online. Teknik pengambilan sampel menggunakan convenience sampling method. Convenience sampling adalah sebagai kumpulan informasi dari anggota-anggota populasi yang mudah diperoleh dan mampu menyediakan informasi tersebut. Dengan demikian siapa saja yang dapat memberikan informasi baik secara tidak sengaja atau kebetulan bertemu dengan peneliti, dapat digunakan sebagai sampel, bila dilihat orang yang memberikan informasi-informasi tersebut cocok sebagai sumber data (Sekaran, 2011)

Kuesioner yang disebar menggunakan skala likert untuk mengukur besarnya persepsi responden atas suatu pernyataan yang diajukan peneliti. Data yang dihasilkankan diuji tingkat kevalidannya dan reliabilitasnya. Validitas adalah tingkat keandalan dan kesahihan alat ukur yang digunakan.intrumen dikatakan valid berarti menunjukkan alat ukur yang dipergunakan untuk mendapatkan data itu valid atau dapat digunakan untuk mengukur apa yang seharusnya di ukur. (Sugiono, 2016)

Dengan demikian, instrumen yang valid merupakan instrument yang benar-benar tepat untuk mengukur apa yang hendak diukur. Perhitungan tingkat validitas dengan korelasi dilakukan dengan rumus teknik korelasi product moment sebagai berikut:

$$
\mathrm{r}=\frac{n \sum X Y-\left(\sum X\right)\left(\sum Y\right)}{\sqrt{n \sum X^{2}-\left(\sum X\right)^{2} x\left(n \sum Y\right)^{2}-\left(\sum Y\right)^{2}}}
$$

Nilai $r$ yang diperoleh dari pehitungan dikonsultasikan dengan nilai rtabel dengan taraf siginfikan 0,05 jika nilai dari $\mathrm{r}>$ rtabel maka pertanyaan tersebut adalah valid.

Sedangkan uji reliabilitas merupakan suatu kestabilan dan konsistensi responden dalam menjawab hal yang berkaitan dengan konstrukkonstruk pertanyaan yang merupakan dimensi suatu variabel dan di susun dalam suatu kuesioner. Uji reliabilitas berguna untuk menetapkan apakah instrumet yang dalam hal ini kuesioner dapat digunakan lebih dari satu kali, paling tidak oleh responden yang sama akan menghasilkan data yang konsisten. Dengan kata lain, reliabilitas mencirikan tingkat konsistensi (Sugiono, 2016). Adapun rumus Alpha Cronbach:

$$
\mathrm{KD}=\mathrm{r}^{2} \times 100 \%
$$


Nilai $r$ yang diperoleh dari perhitungan dikonsultasikan dengan nilai criteria reliabilitas dengan tarif nyata 5\% dari banyaknya responden, selanjutnya jika nilai dari $r \geq 0,60$ maka pertanyaan tersebut adalah reliabel.

Teknik analisis data yang dilakukan dalam penelitian ini adalah analisis regresi berganda dengan bertujuan untuk mengetahui pengaruh secara parsial maupun simultan variabel independen terhadap variabel independen. Analisis yang digunakan adalah regresi berganda dengan data sekunder, maka sebelum menggunakan analisis tersebut terlebih dahulu dilakukan uji asumsi klasik. Adapun persamaan regresi linear berganda yang digunakan adalah sebagai berikut:

$\mathrm{Y}=\beta 0+\beta 1 \mathrm{X} 1+\beta 2 \mathrm{X} 2+\beta 3 \mathrm{X} 3+\beta 4 \mathrm{X} 4+\beta 5 \mathrm{X} 5+\mathrm{e}$

Dimana :

$\begin{array}{lll}\text { Y } & \text { : Kepuasan Nasabah } \\ \beta 0 & \text { : Konstanta } \\ \beta 1 \ldots \beta 5 & \text { Koefisien masing masing variabel } \\ & \text { independen } \\ \text { X1 } & \text { : Reliability and Responsiveness } \\ \text { X2 } & \text { : Assurance and Security } \\ \text { X3 } & \text { : Convenience in Banking } \\ \text { X4 } & \text { : Mobile Banking Efficiency } \\ \text { X5 } & \text { : Easy to Use } \\ \text { e } & \text { : Standar Error }\end{array}$

Analisis ini untuk mengetahui arah hubungan antara variabel independen dengan variabel dependen apakah masing-masing variabel independen berhubungan positif atau negatif dan untuk memprediksi nilai dari variabel dependen apabila nilai variabel independen mengalami kenaikan atau penurunan. menggunakan beberapa uji seperti Uji F (F-test) dan Uji t (t-test). Untuk membuktikan kebenaran hipotesis ketiga, digunakan uji F (F-test) yaitu untuk menguji keberartian koefisiensi secara simultan (keseluruhan) dengan formulasi operasional hipotesis sebagai berikut:

Ho: $b l=b 2=b 3=0$

Ha: $\mathrm{bl} \neq \mathrm{b} 2 \neq \mathrm{b} 3 \neq 0$

Pengujian uji $\mathrm{F}$ adalah dengan membandingkan $\mathrm{F}$ hitung dengan Ftabel pada $\alpha=0,05$ Kesimpulan diperoleh melalui hasil perhitungan sebagai berikut: a) Fhitung > Ftabel, maka Ho ditolak dan $\mathrm{Ha}$ diterima, artinya variabel independennya secara simultan mempengaruhi variabel dependennya; b) Fhitung $\leq$ Ftabel, maka Ho diterima dan Ha ditolak, artinya variabel independennya secara simultan tidak mempengaruhi variabel dependennya.

Sedangkan untuk membuktikan hipotesis, maka digunakan uji t (T-test) yaitu untuk menguji keberartian koefisien regresi parsial dengan menggunakan formulasi hipotesis sebagai berikut:
Ho : $\mathrm{b} 1=0$

Ha : bi $\neq 0$

Pengujian dilakukan melalui uji t (T-test) dengan cara membandingkan $t$ hitung dengan $t$ tabel pada $\alpha$ $=0,05$. Apabila hasil pengujian menunjukkan: a.) $\mathrm{t}$ hitung > t tabel maka Ho ditolak dan Ha diterima. Artinya, variabel independen mempengaruhi secara signifikan terhadap variabel dependen; $b$ ) $t$ hitung $\leq$ t tabel maka Ho diterima dan Ha ditolak. Artinya, variabel independen mempengaruhi variabel dependennya tetapi tidak signifikan. (Sugiono, 2016)

\section{HASIL DAN PEMBAHASAN}

\section{A. Deskripsi Objek Penelitian}

Data hasil penelitian diperoleh sebanyak 100 responden sebagai sampel dengan menyebarkan kuesioner secara online yang berpartisipasi dan menjawab pertanyaan secara penuh. Kuesioner yang disebar mencakup data karakteristik responden seperti jenis kelamin, usia, pendidikan dan pekerjaan. Dari data karakteristik yang ada pada penelitian memiliki persentase untuk jenis kelamin perempuan sebesar 56,5\%, laki-laki sebanyak $43,5 \%$. Usia responden kurang dari 20 sebanyak $10,6 \%$, 20-30 tahun sebanyak 256,3\%, 30-40 tahun sebanyak $37,2 \%$, lebih dari 40 tahun sebanyak $25,9 \%$. Pendidikan untuk tingkat SMU/SMK sederajat sebanyak $18,5 \%$, diploma sebanyak $23,4 \%$, sarjana $30,5 \%$, magister sebayak $26,1 \%$, dan doktoral sebanyak sebesar $1,5 \%$. Profesi pekerjaan sebgai karyawan swasta sebanyak $37,3 \%$, aparatur sipil negara $15,2 \%$, dosen sebanyak $20,5 \%$, guru sebanyak 7,5\%, wiraswasta sebanyak $10,6 \%$, lainnya $8,9 \%$.

\section{B. Uji Validitas dan Reliabilitas}

Uji validitas dan reliabilitas variabel penelitian terhadap responden merupakan prosedur agar data yang diperoleh layak untuk pengujian. Uji ini digunakan untuk menguji data yang menggunakan daftar pertanyaan atau kuesioner untuk melihat pertanyaan dalam kuesioner yang diisi oleh responden tersebut layak atau belum. Hasil pengujian dapat dilihat pada tabel berikut: 
Tabel 1. Uji Validitas

\begin{tabular}{|c|c|c|c|c|}
\hline Variabel & $\begin{array}{c}\text { Item } \\
\text { Pertanyaan } \\
\end{array}$ & $\begin{array}{c}\mathbf{r} \\
\text { hitung } \\
\end{array}$ & $\begin{array}{c}r \\
\text { tabel }\end{array}$ & Ket \\
\hline \multirow{4}{*}{$\begin{array}{l}\text { Reliability and } \\
\text { Responsiveness } \\
\text { (X1) }\end{array}$} & Item_1 & 0.695 & 0.165 & Valid \\
\hline & Item_2 & 0.571 & 0.165 & Valid \\
\hline & Item_3 & 0.772 & 0.165 & Valid \\
\hline & Item_4 & 0.622 & 0.165 & Valid \\
\hline \multirow{4}{*}{$\begin{array}{l}\text { Assurance and } \\
\text { Security } \\
\text { (X2) }\end{array}$} & Item_5 & 0.724 & 0.165 & Valid \\
\hline & Item_6 & 0.675 & 0.165 & Valid \\
\hline & Item_7 & 0.619 & 0.165 & Valid \\
\hline & Item_8 & 0.649 & 0.165 & Valid \\
\hline \multirow{4}{*}{$\begin{array}{l}\text { Convenience in } \\
\text { Banking } \\
\text { (X3) }\end{array}$} & Item_9 & 0.659 & 0.165 & Valid \\
\hline & Item_10 & 0.569 & 0.165 & Valid \\
\hline & Item_11 & 0.575 & 0.165 & Valid \\
\hline & Item_12 & 0.352 & 0.165 & Valid \\
\hline \multirow{3}{*}{$\begin{array}{l}\text { Mobile Banking } \\
\text { Efficiency } \\
\text { (X4) }\end{array}$} & Item_13 & 0.441 & 0.165 & Valid \\
\hline & Item_14 & 0.696 & 0.165 & Valid \\
\hline & Item_15 & 0.517 & 0.165 & Valid \\
\hline \multirow{3}{*}{$\begin{array}{l}\text { Easy to Use } \\
\text { (X5) }\end{array}$} & Item_16 & 0.352 & 0.165 & Valid \\
\hline & Item_17 & 0.377 & 0.165 & Valid \\
\hline & Item_18 & 0.741 & 0.165 & Valid \\
\hline Variabel & $\begin{array}{c}\text { Item } \\
\text { Pertanyaan } \\
\end{array}$ & $\begin{array}{c}\mathbf{r} \\
\text { hitung } \\
\end{array}$ & $\begin{array}{c}r \\
\text { tabel }\end{array}$ & Ket \\
\hline \multirow{4}{*}{$\begin{array}{c}\text { Kepuasan } \\
\text { Nasabah (Y) }\end{array}$} & Item_1 & 0.538 & 0,165 & Valid \\
\hline & Item_2 & 0.485 & 0,165 & Valid \\
\hline & Item_3 & 0.593 & 0,165 & Valid \\
\hline & Item_4 & 0.526 & 0,165 & Valid \\
\hline
\end{tabular}

Sumber: Hasil Penelitian (2020)

Berdasarkan hasil pengolahan data pada tabel diatas, item pertanyaan pada setiap variabel yang digunakan menujukkan semuanya valid, sebab nilai $r$ hitung lebih besar dari nilai $r$ tabel ( $r$ hitung $>r$ tabel). Sedangkan untuk uji reliabilitas pada setiap variabel yang digunakan pada penelitian, dapat dilihat pada tabel berikut ini:
Tabel 2. Uji Reliabilitas

\begin{tabular}{cccc}
\hline Variabel & $\begin{array}{c}\text { Cronbach } \\
\text { Alpha }\end{array}$ & Standar & Ket \\
\hline $\begin{array}{c}\text { Reliability and } \\
\text { Responsiveness } \\
\text { (X1) }\end{array}$ & 0.874 & 0.60 & Reliabel \\
\hline $\begin{array}{c}\text { Assurance and } \\
\text { Security (X2) }\end{array}$ & 0.762 & 0.60 & Reliabel \\
\hline $\begin{array}{c}\text { Convenience in } \\
\text { Banking (X3) }\end{array}$ & 0.775 & 0.60 & Reliabel \\
\hline $\begin{array}{c}\text { Mobile Banking } \\
\text { Efficiency (X4) }\end{array}$ & 0.734 & 0.60 & Reliabel \\
\hline $\begin{array}{c}\text { Easy to Use } \\
\text { (X5) }\end{array}$ & 0.714 & 0.60 & Reliabel \\
\hline $\begin{array}{c}\text { Kepuasan } \\
\text { Nasabah (Y) }\end{array}$ & 0.762 & 0.60 & Reliabel \\
\hline Sumber: Hasil Penelitian (2020) & &
\end{tabular}

Sumber: Hasil Penelitian (2020)

Berdasarkan hasil pengolahan data yang tersaji dalam tabel 2, semua variabel dalam penelitian ini reliabel, hal itu dapat dilihat dari nilai cronbach alpha pada semua variabel memiliki nilai yang lebih besar dari nilai standar.

\section{Uji Asumsi Klasik}

\section{Uji Normalitas}

Uji normalitas digunakan sebagai langkah awal untuk mengetahui dalam model regresi penelitian apakah terdapat variabel pengganggu atau residual yang memiliki distribusi normal atau tidak.. Hasil uji normalitas data pada penelitian ini dilihat sebagai berikut:

\section{Normal P-P Plot of Regression Standardized
Residual}

Dependent Variable: $Y$

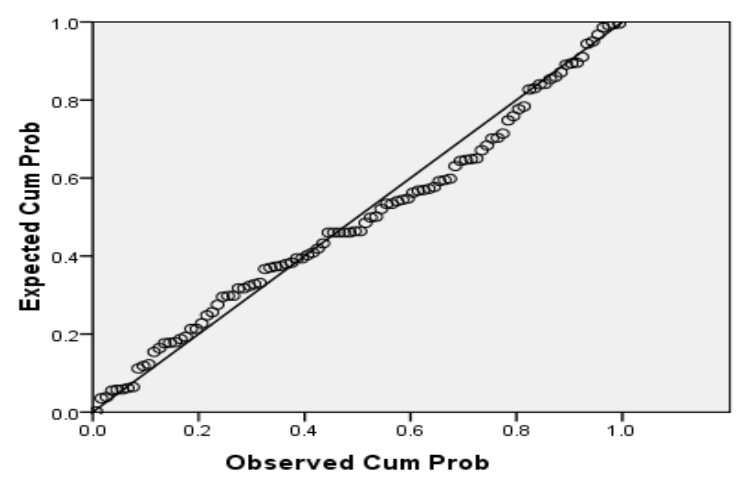

Sumber: Hasil Penelitian (2020)

Gambar 1. Diagram Plot Normalitas Data 


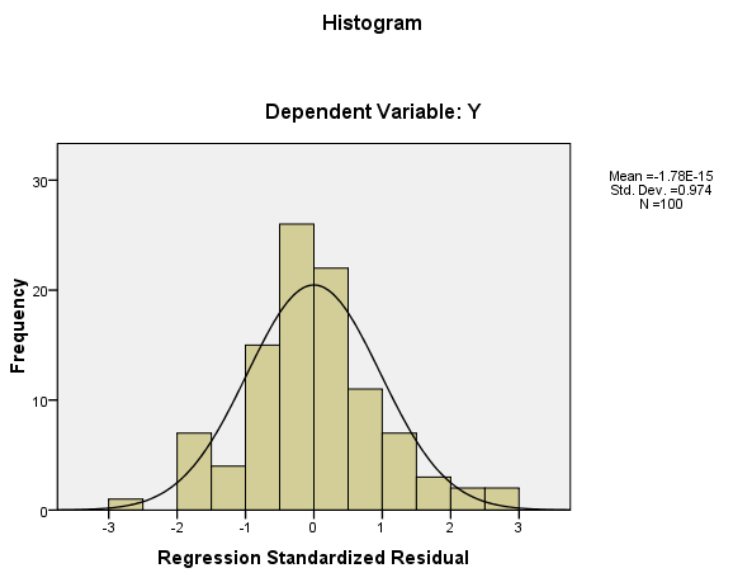

Sumber: Hasil Penelitian (2020)

Gambar 2. Grafik Histogram

Berdasarkan uji normalitas pada gambar 1 dan 2 dengan menggunakan grafik dapat dilihat bahwa titik-titik menyebar disekitar garis diagonal atau mengikuti arah garis diagonal. Dengan demikian dapat disimpulkan bahwa semua variabel telah terdistribusi normal dan model regresi layak digunakan.

\section{Uji Multikolinieraritas}

Uji multikolinieritas diperlukan untuk mengetahui ada tidaknya variabel independen yang memiliki kemiripan dengan variabel independen lain dalam satu model. Hasil uji multikolinieritas pada penelitian ini dilihat sebagai berikut:

Tabel 3. Uji Multikolinearitas

\begin{tabular}{ccc} 
Variabel & Tolerence & VIP \\
\hline $\mathrm{X} 1$ & 0.798 & 1.253 \\
\hline $\mathrm{X} 2$ & 0.824 & 1.232 \\
\hline $\mathrm{X} 3$ & 0.802 & 1.248 \\
\hline $\mathrm{X} 4$ & 0.727 & 1.376 \\
\hline $\mathrm{X} 5$ & 0.734 & 1.381 \\
\hline
\end{tabular}

Sumber: Hasil Penelitian (2020)

Hasil uji melalui Variance Inflation Factor (VIP) pada hasil output SPSS tabel Coefficients, seluruh variabel menujukkan nilai tolerance $>0,1$ dan VIF < 10, maka dapat dinyatakan model regresi linier berganda terbebas dari multikolinearitas dan dapat digunakan dalam penelitian

\section{Uji Autokorelasi}

Autokorelasi merupakan korelasi antara anggota observasi yang disusun menurut waktu atau tempat. Model regresi yang baik seharusnya tidak terjadi autokorelasi. Hasil uji autokorelasi pada penelitian ini dapat dilihat pada tabel berikut:
Tabel 4. Uji Autokorelasi

\begin{tabular}{l}
\hline Durbin-Watson \\
\hline 1.972 \\
Sumber: Hasil Penelitian (2020) \\
Dari hasil output SPSS didapatkan nilai Durbin- \\
Watson untuk model regresi Kepuasan Nasabah \\
sebagai variabel dependen senilai 2,477. Hasil nilai \\
Durbin-Watson hitung terletak diantara batas atas \\
(du) dan batas bawah (4-du) atau du < dw $<$ 4-du \\
yaitu 1,571 < 1,972 < 2,220 sehingga keputusan \\
yang diambil adalah tidak adanya autokorelasi \\
negatif dan positif atau dengan kata lain tidak ada \\
autokorelasi dalam model regresi ini. Dengan \\
demikian dapat dikatakan bahwa model terbebas \\
dari autokorelasi.
\end{tabular}

\section{Uji Heteroskedastisitas}

Pengujian heteroskedastisitas digunakan untuk melihat apakah dalam model regresi terjadi ketidaksamaan dari pengamatan satu kepengamatan lainnya. Model regresi dalam penelitian dikatakan baik apabila terhindar atau terbebas dari heteroskedastisitas. Hasil uji heteroskedastisitas pada penelitian ini dapat dilihat pada gambar dibawah ini:

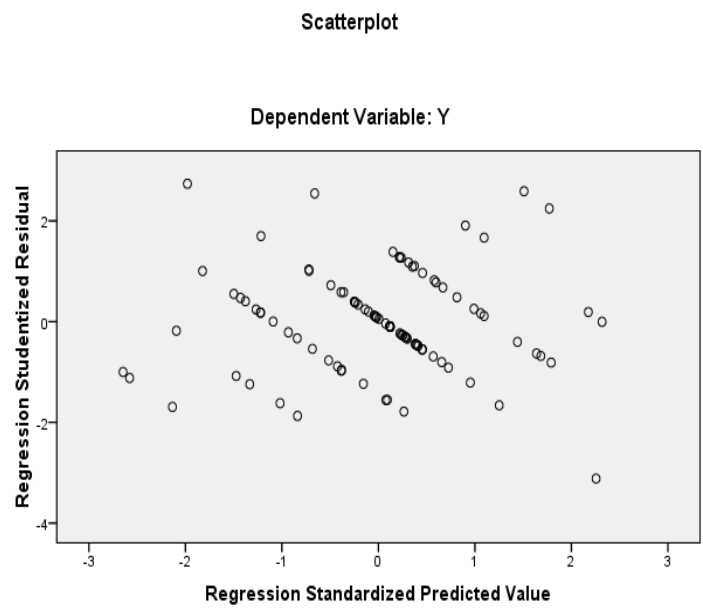

Sumber: Hasil Penelitian (2020)

Gambar 3. Grafik Scatterplot

Dari grafik scatterplot terlihat bahwa titik-titik menyebar secara acak serta tersebar baik diatas maupun dibawah angka 0 pada sumbu $\mathrm{Y}$ dengan demikian dapat disimpulkan bahwa model regresi ini tidak terjadi heteroskedastisitas.

\section{Analisis Regresi Berganda}

Hasil perhitungan Regresi Linier Berganda dapat dilihat pada tabel berikut: 
Tabel 5. Hasil Regresi Berganda

\begin{tabular}{cccc}
\multirow{2}{*}{ Model } & \multicolumn{2}{c}{$\begin{array}{c}\text { Unstandardized } \\
\text { Coefficients }\end{array}$} & $\begin{array}{c}\text { Standardized } \\
\text { Coefficients }\end{array}$ \\
\cline { 2 - 5 } & $\mathrm{B}$ & $\begin{array}{c}\text { Std. } \\
\text { Error }\end{array}$ & \multicolumn{2}{c}{ Beta } \\
\hline $1 \quad$ (Constant) & 5.549 & 1.260 & \\
\hline $\mathrm{X} 1$ & 0.086 & 0.029 & 0.202 \\
\hline $\mathrm{X} 2$ & 0.078 & 0.026 & 0.237 \\
\hline $\mathrm{X} 3$ & 0.237 & 0.032 & 0.513 \\
\hline $\mathrm{X} 4$ & 0.120 & 0.030 & 0.289 \\
\hline $\mathrm{X} 5$ & 0.154 & 0.037 & 0.293 \\
\hline
\end{tabular}

a. Dependent Variable: $\mathrm{Y}$

Sumber: Hasil Penelitian (2020)

Berdasarkan hasil pada tabel 5 diperoleh persamaan regresi sebagai berikut:

$$
\begin{aligned}
& Y=5,549+0,086 \times 1+0,078 \times 2+0,237 X 3+ \\
& 0,120 X 4+0,154 \times 5+\varepsilon
\end{aligned}
$$

Intrepretasi dari persamaan regresi linier berganda tersebut adalah:

Nilai konstanta (a) sebesar 5.549. Hal ini menunjukkan bahwa jika variabel independen Reliability and Responsiveness (X1), Assurance and Security (X2), Convenience in Banking (X3), Mobile Banking Efficiency (X4), Easy to Use (X5) diasumsikan dalam keadaan tetap, maka variabel dependen Kepuasan Nasbah (Y) akan naik sebesar 5.549

Nilai koefisien regresi Reliability and Responsiveness (X1), bernilai positif yaitu sebesar 0,086 yang berarti jika variabel Reliability and Responsiveness (X1) naik sebesar 1 satuan dengan asumsi variabel independen lain nilainya tetap, maka Kepuasan nasabah akan naik sebesar 0,086 satuannya.

Nilai koefisien regresi Assurance and Security (X2), bernilai positif yaitu sebesar 0,078 yang berarti jika variabel Assurance and Security (X2) naik sebesar 1 satuan dengan asumsi variabel independen lain nilainya tetap, maka Kepuasan nasabah akan naik sebesar 0,078 satuannya.

- Nilai koefisien regresi Convenience in Banking (X3) bernilai positif yaitu sebesar 0,237 yang berarti jika variabel Convenience in Banking (X3) naik sebesar 1 satuan dengan asumsi variabel independen lain nilainya tetap, maka Kepuasan nasabah akan naik sebesar 0,237 satuannya.

Nilai koefisien regresi Mobile Banking Efficiency (X4) bernilai positif yaitu sebesar 0,120 yang berarti jika variabel Mobile Banking Efficiency (X4) naik sebesar 1 satuan dengan asumsi variabel independen lain nilainya tetap, maka Kepuasan nasabah akan naik sebesar 0,120 satuannya.

Nilai koefisien regresi Easy to Use (X5) bernilai positif yaitu sebesar 0,154 yang berarti jika variabel Easy to Use (X5) naik sebesar 1 satuan dengan asumsi variabel independen lain nilainya tetap, maka Kepuasan nasabah akan naik sebesar 0,154 satuannya.

\section{E. Analisa Koefisien Determinasi $\left(\mathbf{R}^{2}\right)$}

Koefisien determinasi $\left(\mathrm{R}^{2}\right)$ digunakan untuk mengukur seberapa jauh kemampuan model dalam menerangkan variasi variable dependennya. Nilai $\mathrm{R}^{2}$ yang mendekati satu berarti variable-variabel independennya memberikan hampir semua informasi yang dibutuhkan untuk memprediksi variasi variabel dependen. Hasil perhitungan koefisien determinasi dapat dilihat pada tabel berikut:

\begin{tabular}{|c|c|c|c|c|}
\hline \multicolumn{5}{|c|}{ Model Summary } \\
\hline Model & $\mathrm{R}$ & $\begin{array}{c}\mathrm{R} \\
\text { Square }\end{array}$ & $\begin{array}{l}\text { Adjusted } \\
\text { R Square }\end{array}$ & $\begin{array}{l}\text { Std. } \\
\text { Error of } \\
\text { the } \\
\text { Estimate }\end{array}$ \\
\hline 1 & $.801^{\mathrm{a}}$ & .642 & .622 & .67601 \\
\hline
\end{tabular}

Tabel 6. Koefisien Determinasi

a. Predictors: (Constant), X5, X2, X3, X1, X4

b. Dependent Variable: Y

Sumber: Hasil Penelitian (2020)

Berdasarkan hasil pada tabel 6 pengujian koefisien determinasi $\mathrm{R}$ Square $\left(\mathrm{R}^{2}\right)$ Kepuasan Nasabah diperoleh nilai sebesar 0,642. Dengan kata lain hal ini menunjukkan bahwa besar presentase variasi Kepuasan Nasabah yang bisa dijelaskan oleh variasi dari kelima variabel bebas yaitu Reliability and Responsiveness (X1), Assurance and Security (X2), Convenience in Banking (X3), Mobile Banking Efficiency (X4), Easy to Use (X5) sebesar 64,2\%, sedangkan sisanya sebesar $35,8 \%$ dijelaskan oleh sebab-sebab lain diluar model penelitian yang digunakan.

\section{F. Hasil Uji F}

Uji $\mathrm{F}$ digunakan untuk mengetahui pengaruh variabel bebas secara bersama-sama (simultan) terhadap variabel terikat. Hasil perhitungan uji $\mathrm{F}$ dapat dilihat pada tabel berikut: 
Tabel 7. Hasil Uji F

ANOVA $^{b}$

\begin{tabular}{clcccc}
\hline Model & & $\begin{array}{c}\text { Sum of } \\
\text { Squares }\end{array}$ & df & F & Sig. \\
\hline \multirow{2}{*}{1} & Regression & 76.883 & 5 & 33.647 & $.000^{\mathrm{a}}$ \\
& Residual & 42.957 & 94 & & \\
& Total & 119.840 & 99 & & \\
\hline
\end{tabular}

a. Predictors: (Constant), X5, X2, X3, X1, X4

b. Dependent Variable: Y

Sumber: Hasil Penelitian (2020)

Berdasarkan hasil output pada tabel 7 menunjukkan bahwa F-hitung (F-Statitstik) sebesar 33,647 sedangkan F-tabel dengan df $2(\mathrm{n}-\mathrm{k}-1)=94$ adalah 3,093 dengan demikian F-Hitung > F-Tabel $(33,647$ $>3,093)$ pada tingakt signifikansi $<0,05(0,000<$ $0,05)$ artinya semua variabel independen secara bersama-sama berpengaruh signifikan terhadap variabel dependen.

\section{H. Hasil Uji t}

Pengujian ini dilakukan untuk mengetahui apakah terdapat pengaruh dari masing-masing variabel bebas terhadap variabel terikat. Uji ini dapat dilakukan dengan melihat kolom signifikansi dengan membandingkan tingkat signifikansi 5\% $(\alpha=0,05)$. Hasil uji t dapat diketahui melalui tabel berikut ini:

Tabel 8. Hasil Uji t

Coefficients $^{\mathrm{a}}$

\begin{tabular}{llll}
\hline & Model & $\mathrm{t}$ & Sig. \\
\hline 1 & (Constant) & 4.405 & 0.000 \\
\hline $\mathrm{X} 1$ & 2.917 & 0.004 \\
\hline $\mathrm{X} 2$ & 2.325 & 0.016 \\
\hline $\mathrm{X} 3$ & 7.444 & 0.000 \\
\hline $\mathrm{X} 4$ & 3.982 & 0.000 \\
\hline $\mathrm{X} 5$ & 3.455 & 0.007 \\
\hline
\end{tabular}

a. Dependent Variable: $Y$

Sumber: Hasil Penelitian (2020)

Hasil perhitungan pada tabel 8 diperoleh nilai t dapat dicari dengan level of signifi cance (a) $=0,05$ dan derajat tabel kebebasan (degree of freedom $=\mathrm{df}$ ) $=$ $\mathrm{n}-\mathrm{k}-1$, maka besarnya nilai t-tabel dapat ditentukan sebagai berikut: $\mathrm{t}$-tabel adalah a ; $\mathrm{n}-\mathrm{k}=0,05 ;(100$ $6)=1,661$. Adapun cara pengujian uji $\mathrm{t}$ untuk masing-masing variabel adalah sebagai berikut:

Hipotesis 1 menunjukan terdapat pengaruh positif dan signifikan variabel reliability and responsiveness (X1) terhadap kepuasan nasabah.
Pembuktian untuk hipotesis tersebut digunakan perbandingan t-hitung dengan t-tabel, dimana diperoleh nilai t-hitung lebih besar dari pada t-tabel $(2,917>1,661)$. Hasil nilai p-value sebesar $0,004<$ 0,05 (alpha 5\%), maka Ha diterima dan disimpulkan secara statistik pada tingkat kepercayaan 95\% terdapat pengaruh positif reliability and responsiveness (X1) terhadap kepuasan nasabah. Hasil penelitain ini sesuai dengan penelitian Gangsar Prawiramulia (2014), Aditya Wardhana (2015) dan Hikmatul Wasilah (2016) yang menyatakan bahwa reliability and responsiveness berpengaruh positif terhadap kepuasan nasabah.

Hipotesis 2 menunjukan terdapat pengaruh positif dan signifikan variabel assurance and security (X2) terhadap kepuasan nasabah. Pembuktian untuk hipotesis tersebut digunakan perbandingan t-hitung dengan t-tabel, dimana diperoleh nilai t-hitung lebih besar dari pada t-tabel $(2,325>1,661)$. Hasil nilai $p$ value sebesar 0,016 < 0,05 (alpha 5\%), maka Ha diterima dan disimpulkan secara statistik pada tingkat kepercayaan $95 \%$ terdapat pengaruh positif assurance and security (X2) terhadap kepuasan nasabah. Hasil penelitain ini sesuai dengan penelitian Aditya Wardhana (2015) dan Hikmatul Wasilah (2016) yang menyatakan bahwa assurance and security berpengaruh positif terhadap kepuasan nasabah.

Hipotesis 3 menunjukan terdapat pengaruh positif dan signifikan variabel convenience in banking (X3) terhadap kepuasan nasabah. Pembuktian untuk hipotesis tersebut digunakan perbandingan t-hitung dengan t-tabel, dimana diperoleh nilai t-hitung lebih besar dari pada t-tabel $(7,444>1,661)$. Hasil nilai $p$-value sebesar $0,016<$ 0,05 (alpha 5\%), maka Ha diterima dan disimpulkan secara statistik pada tingkat kepercayaan 95\% terdapat pengaruh positif convenience in banking (X3) terhadap kepuasan nasabah. Hasil penelitain ini sesuai dengan penelitian Gangsar Prawiramulia (2014) yang menyatakan bahwa convenience in banking berpengaruh positif terhadap kepuasan nasabah.

Hipotesis 4 menunjukan terdapat pengaruh positif dan signifikan variabel mobile banking efficiency (X4) terhadap kepuasan nasabah. Pembuktian untuk hipotesis tersebut digunakan perbandingan t-hitung dengan t-tabel, dimana diperoleh nilai t-hitung lebih besar dari pada ttabel $(3,982>1,661)$. Hasil nilai $p$-value sebesar $0,016<0,05$ (alpha 5\%), maka Ha diterima dan disimpulkan secara statistik pada tingkat kepercayaan $95 \%$ terdapat pengaruh positif mobile banking efficiency (X4) terhadap kepuasan nasabah. Hasil penelitain ini sesuai dengan penelitian Aditya Wardhana (2015) yang menyatakan bahwa mobile banking efficiency berpengaruh positif terhadap kepuasan nasabah.

Hipotesis 5 menunjukan terdapat pengaruh positif dan signifikan variabel easy to use (X5) 
terhadap kepuasan nasabah. Pembuktian untuk hipotesis tersebut digunakan perbandingan $\mathrm{t}$ hitung dengan t-tabel, dimana diperoleh nilai thitung lebih besar dari pada t-tabel $(3,455>$ 1,661). Hasil nilai $p$-value sebesar $0,016<0,05$ (alpha 5\%), maka Ha diterima dan disimpulkan secara statistik pada tingkat kepercayaan 95\% terdapat pengaruh positif easy to use (X5) terhadap kepuasan nasabah. Hasil penelitain ini sesuai dengan penelitian Gangsar Prawiramulia (2014) yang menyatakan bahwa easy to use berpengaruh positif terhadap kepuasan nasabah.

\section{KESIMPULAN}

Dari hasil penelitian ini disimpulkan bahwa Kualitas Mobile Banking Terhadap Kepusan Nasabah secara keseluruhan memperoleh hasil yang positif dan signifikan. PT Bank Rakyat Indonesia (Persero), Tbk untuk elemen reliability and responsivness merujuk pada kemampuan perusahaan memberikan layanan secara akurat kepada pelanggannya dan bentuk tindakan perusahaan dalam merespons pelanggan secara tepat waktu, sudah dilakukan dengan baik. Hal ini terlihat dimana PT Bank Rakyat Indonesia (Persero), Tbk menghadirkan produk dan layanan yag dapat diakses oleh nasabah kapan saja dan di mana saja serta tanggap membantu nasabah untuk memberikan solusi untuk setiap permasalahan yang dihadapi baik untuk setiap keluhan dan komplain dari nasabah.

Elemen assurance and security yang mengacu pada kemampuan perusahaan untuk menumbuhkan kepercayaan di mata pelanggan melalui keramahan dan pengetahuan staf dalam melayani serta melindungi kemananan transaksi nasabah dilakukan dengan baik oleh PT Bank Rakyat Indonesia (Persero), Tbk. Salah satu upayanya adalah melakukan enhancement keamanan di teknologi echannel BRI.

Pada elemen convenience in banking yang merupakan persepsi konsumen terhadap kemudahan waktu dan usaha yang berkaitan dengan pembelian atau pemakaian suatu jasa, PT Bank Rakyat Indonesia (Persero), Tbk selalu berupaya memberikan yang terbaik,

Untuk elemen mobile banking efficiency dalam hal ini PT Bank Rakyat Indonesia (Persero), Tbk menyediakan aplikasi yang mengitegrasikan beberapa aplikasi e-banking BRI yang dapat diakses melalui smartphone tanpa harus datang ke kantor Bank, sehingga urusan keuangan jadi lebih efisien.

Kemudahan dalam penggunaan mobile banking (easy to use), PT Bank Rakyat Indonesia (Persero), Tbk menghadirkan fitur layanan perbankan yang dapat dipahami dan dipelajari para nasabahnya dalam waktu singkat, sehingga membantu transaksi perbankan.

\section{REFERENSI}

Jayani, D. H. (2019). Berapa Pengguna Internet di Indonesia? Retrieved January 2, 2020, from https://databoks.katadata.co.id/datapublish/201 9/09/09/berapa-pengguna-internet-diindonesia

Kotler, Philip., \& Keller, K. L. (2012). Manajemen Pemasaran (13th ed.). Jakarta: Erlangga.

Kurniawati, Hanif Astika, E. a. (2017). Analisis Minat Penggunaan Mobile Banking Dengan Pendekatan Technology Acceptance Model (TAM) Yang Telah Dimodifikasi. E-Journal Ekonomi Dan Bisnis Uiversitas Jember, 4 No. 1.https://doi.org/https://doi.org/10.19184/ejeba .v4i1.4563

Parasuraman, A., Valarie., Zeithaml \& Malhotra, A. (2005). E-S-QUAL. A multiple Item Scale for Accessing Electrionic Service Quality. Journal of Service Research (Vol. 7, No. X). Carolina: Sage Publications.Universiy of North Carolina at Chapel Hill

Prawiramulia, Gangsar. (2014). Pengaruh Kualitas Mobile Banking Terhadap Kepuasan Nasabah Bank Mandiri (Studi Pada Pengguna Mandiri Mobile Di Kota Bandung), eProceedings of Management, $\quad 1 \quad 10$. https://libraryeproceeding.telkomuniversity.ac.i $\mathrm{d} /$ index.php/management/article/view/3158

Sekaran, U. (2011). Research Methods For Business (Metode Penelitian untuk Bisnis). (4th ed.). Jakarta: Salemba Empat.

Sugiono. (2016). Metode Penelitian Kuantitatif, Kualitatif dan $R \& D$. Bandung: Alfabeta.

Wardhana, A. (2015). Pengaruh Kualitas Layanan Mobile Banking (M-Banking) Terhadap Kepuasan Nasabah Di Indonesia [Effect Of Mobile Banking (M-Banking) Service Quality On Customer Satisfaction In Indonesia]. DeReMa Jurnal Manajemen, 10, 273-284. https://doi.org/http://dx.doi.org/10.19166/dere ma.v10i2.164

Wasilah, Hikmatul. (2016). Pengaruh Layanan Mobile Banking Terhadap Kepuasan Nasabah BRI Syariah Cabang Mataram. Repository UIN Mataram.http://etheses.uinmataram.ac.id/225/1 /Hikmatul\%20Wasilah151115045.pdf 